\title{
Teachers' Sense of Efficacy Scale: Confirming the Factor Structure on Indonesian Elementary Teachers
}

\author{
Lina Puspitaning Rahayu, Graduate School of Universitas Negeri Yogyakarta, Indonesia, \\ linapuspitaning.2018@student.uny.ac.id,ORCID:0000-0001-7361-3420 \\ Muhammad Nur Wangid, Graduate School of Universitas Negeri Yogyakarta, Indonesia, \\ m_nurwangid@uny.ac.id, ORCID:0000-0003-0348-9238
}

\begin{abstract}
These study aims are to: 1) describe the development of Indonesian version of Teachers' Sense of Efficacy Scale (I-TSES); 2) provide evidence for the construct validity of the three-factor subscales using Confirmatory Factor Analysis (CFA); and 3) obtain evidence the internal consistency reliability of each three-factor subscale and the overall instrument. The participants in this study were 95 elementary teachers in Indonesia. Confirmatory Factor Analysis using Lisrel 8.80 shows that the original I-TSES model fits data poorly. The model was modified until the fifth revision and the fit of the model was improved. Internal consistency reliability coefficients indicate a strong value. The revised I-TSES can be used as valid and reliable measurement tools to assess teachers' self-efficacy in Indonesian. This research can be used for assessing the extent of teacher performance in teaching in Indonesia.
\end{abstract}

Keywords: Confirmatory factor analysis, self-efficacy, self-efficacy measurement, self-efficacy scale.

Received: 16.11 .2020

Accepted: 13.12 .2020

Published: 05.01 .2021

\section{INTRODUCTION}

A teacher is one of the important factors that define the success of teaching-learning activities in class. Some affective factors that teachers have, such as self-efficacy, can affect the teaching activities done by the teacher in the class (Abu-tineh, Khasawneh, \& Khalaileh, 2011; Dembo \& Gibson, 1985; Liu \& Hallinger, 2018; Putman, 2012). Self-efficacy is a belief in someone's ability to set and perform necessary actions to manage the expected situation (Bandura, 1997, p. 2). For teachers, self-efficacy acts as a variable that causes individual difference in each teacher, has strong relationship to learning and achievement (Chang, 2015; Saklofske, Michayluk, \& Randhawa, 1988), and has positive relationship to student's academic adjustment and class management done by teachers (Zee \& Koomen, 2016).

Some researchers also state in their studies that teacher's self-efficacy has an influence on learning taught in class. A research shows that teacher's self-efficacy influence learning mathematic (Chang, 2015; Giles, Byrd, \& Bendolph, 2016; Gür, Çakiroğlu, \& Çapa, 2012; Nurlu, 2015); science (Bergman \& Morphew, 2015; Senler, 2016); and music (Biasutti \& Concina, 2018). Furthermore, teacher's self-efficacy affects teacher's efforts in teaching, the expected goal, and their level of hope (Clark \& Newberry, 2018; Tschannen-moran \& Hoy, 2001). Moreover, this research shows that teachers' competence will increase when their self-efficacy improves (Septiana, 2018). The teachers with high self-efficacy have a different level of efforts with the teachers with low self-efficacy (Tschannen-Moran, Hoy, \& Hoy, 1998).

Teachers with high self-efficacy tend to have faith in themselves being able to teach lessons and to find the best way to teach their students effectively (Santrock, 2011). Teachers with high self-efficacy give more positive encouragement in the class than the teachers with low self-efficacy do (Guo, Connor, Yang, Roehrig, \& Morrison, 2012). When the teachers are capable to teach the lessons effectively and efficiently, it will affect students' achievement in learning (Kim \& Seo, 2018; Swanson, 2014; Wahyuni \& Jailani, 2017).

On the contrary, teachers with the low self-efficacy tend to give up easily when teaching students (Tschannen-Moran et al., 1998) and claim that students have low capability in learning so that they are not capable of performing in the learning activities (Santrock, 2011). Furthermore, teachers with low selfefficacy tend to be pessimistic on students' capability to follow the lessons well; they do not have the willingness to find the way out and effective learning strategy in order to make the students understand 
better (Santrock, 2011). Therefore, having high self-efficacy is essential for the teacher in managing the learning activities in the class.

Self-efficacy control over potential threats and determine how long someone will stand in the face of obstacle (Bandura, 1977, 1988; Chan, 2008). Elementary school teachers who have low self-efficacy experience a high level of anxiety because they cannot manage potential threats (Bandura, 1988). Anxiety can cause problems for both the teacher themselves and their students (Coates \& Thoresen, 1976). Research also shows that teachers who have anxiety in teaching will transmit such anxiety to their students (Bekdemir, 2010; Ramirez, Hooper, Kersting, Ferguson, \& Yeager, 2018) and have high levels of stress and depression because they cannot manage challenges and threats (Bandura, 1993). The statement shows the importance of an elementary school teacher having high self-efficacy.

An important starting point to improve elementary school teachers' self-efficacy is to provide preservice teachers with various skills while at university (Arsal, 2014; Buss, 2010; Clark \& Newberry, 2018; Evans, Tomas, \& Woods, 2016; Menon \& Sadler, 2016) and teacher training program (Cansoy \& Parlar, 2018; Chao, Forlin, \& Ho, 2016; Forlin, Sharma, \& Loreman, 2014). On the other hand, various measurement tools should be used to determine the level of elementary school teachers' self-efficacy. A review of related literature shows that there is only a limited number of measurement tools that can be used to measure the level of elementary school teachers' self-efficacy.

Several instruments have been developed by experts to measure teacher's self-efficacy, such as Teacher Self-efficacy Scale (Bandura, 2005); Teacher Efficacy Scale (Gibson \& Dembo, 1984); and Teachers' Sense of Efficacy Scale (Tschannen-moran \& Hoy, 2001). The Teacher Self-efficacy Scale (Bandura, 2005) consists of 28 items and uses a scale of 0 to 100. There is no explanation whether the instrument is used for elementary school teachers, middle school teachers or even for prospective teachers.

The Teacher Efficacy Scale developed by Gibson \& Dembo (1984) consists of 30 statements with a scale of 1 (strongly disagree) to 6 (strongly agree). Teacher Efficacy Scale consists of 2 indicators, namely personal teaching efficacy and teaching efficacy. The targets of this scale are elementary in-service teachers. The Teachers' Sense of Efficacy Scale or TSES (Tschannen-moran \& Hoy, 2001) consists of 24 items. The targets of the TSES instrument are teachers in general (in-service teachers) and preservice teachers.

Many researchers have investigated the construct of elementary school teachers' self-efficacy by using Teacher Self-efficacy Scale, Teacher Efficacy Scale, and Teachers' Sense of Efficacy Scale. However, Tschannen-moran \& Hoy (2001) reported two shortcomings of Teacher Self-efficacy Scale. First, the items mentioned in the Teacher Self-efficacy Scale did not reflect the kinds of teacher tasks at school (Tschannen-moran \& Hoy, 2001). Second, there is no information about the validity and reliability of the Teacher Self-efficacy Scale (Tschannen-moran \& Hoy, 2001). On the other hand, the Teacher Efficacy Scale (Gibson \& Dembo, 1984) also have shortcomings. First, Woolfolk \& Hoy (1990) revealed that the indicators presented by Gibson \& Dembo had different meaning with the Bandura dimension. Second, Tschannen-moran \& Hoy (2001) explains that the shortcoming of the Teacher Efficacy Scale is a lack of clarity about the meaning of two factors and the instability of the factor structure.

In order to overcome the mentioned shortcomings, Tschannen-moran \& Hoy (2001) restudied the Teacher Self-efficacy Scale and Teacher Efficacy Scale (TSES) to develop a new measurement tool. TSES provides information related to instrument validation and scale development, and the article contains instruments, factor analysis, and cultural influences as well (Kleinsasser, 2014, p. 170). In addition, TSES has been adapted into various languages, for example, adaptations into Turkish (Çapa, Çakıroğlu, \& Sarıkaya, 2005) and Malay (Murshidi, Konting, Elias, \& Fooi, 2006). TSES is a valid and reliable instrument when used to measure the self-efficacy of elementary school teachers in western countries and when adapted by various countries. Murshidi et al. (2006) stated that the reliabilities of overall TSES, instructional strategies, classroom management, and student engagement when used in Malaysia, were $.97, .94, .93$ and .93 , respectively. Furthermore, Çapa et al. (2005) stated that the reliabilities of overall TSES, instructional strategies, classroom management, and student engagement, when used in Turkey, were $.93, .86, .84$, and .82 .

Some literature explains that self-efficacy differs based on race or ethnicity in each country (Murshidi et al., 2006). Cheung (2008) found differences in self-efficacy of elementary school teachers in Hong Kong and Shanghai. Furthermore, Yada et al. (2019) also found differences in teachers' self-efficacy in Japan and Finland. Therefore, there may be differences in self-efficacy in Indonesia.

To measure self-efficacy in Indonesia, need a valid and reliable measurement tool because there are no measurement tools to measure the self-efficacy of elementary school teachers in Indonesia. However, TSES has not been studied and adapted in the Indonesian population. Therefore, the researcher intends to adapt TSES into Indonesian. 
This study tries to answer previous research suggestions in which it is necessary to examine the factor structure, assess the validity of TSES, and examine the cultural suitability of the TSES construct (Duffin, French, \& Patrick, 2012). This study aims to assess whether TSES can be used in Indonesia with the adaptation of language into Indonesian. There are three objectives of this study, including: 1) describing the adaptation of Teachers' Sense of Efficacy Scale (TSES) in Indonesian version; 2) assess the construct validity of three subscales using Confirmatory Factor Analysis (CFA); and 3) assess the internal consistency reliability of each subscale and the instrument entirely.

\section{METHODS}

\section{Sample of Research}

Participants were elementary school teachers in Purbalingga District. Participants were selected using proportional stratified sampling techniques because the number of male and female teachers were imbalanced. The population was 105 elementary school teachers, and the minimum sample size was calculated using formula Krejcie \& Morgan (1970) that is, $s=\frac{X^{2} N P(1-P)}{d^{2}(N-1)+X^{2} P(1-P)}$. From this formula, a minimum sample obtained was 32 male elementary school teachers and 51 female elementary school teachers. In this research, research participants were 95 elementary school teachers, consisting of 57 female and 38 male elementary school teachers. Demographic characteristics of the sample are presented in Table 1.

Table 1. Demographic characteristics of the sample

\begin{tabular}{|c|c|c|}
\hline Gender & f & \% \\
\hline Male & 38 & 40 \\
\hline Female & 57 & 60 \\
\hline Total & $\mathbf{9 5}$ & $\mathbf{1 0 0}$ \\
\hline
\end{tabular}

\section{Instrument}

TSES is an instrument consisting of 3 subscales. They are efficacy for student engagement, efficacy for instructional strategies, and efficacy for classroom management. TSES, which is nine-point Likert scale, has a scoring from 1 (nothing) to 9 (a great deal).

TSES consists of 2 forms: long-form consisting of 24 items and short-form consisting of 12 items. Both can be used as valid and reliable instruments to measure teacher's self-efficacy. Both versions have an overall scale reliability coefficient of .94 for the long-form version and .90 for the short-form version. The reliability coefficient of each efficacy for student engagement subscale, efficacy for instructional strategies, and efficacy for classroom management were .87; .91; and .90 for the long-form and .81; .86; and .86 for short-form (Tschannen-moran \& Hoy, 2001).

Here are examples of items of TSES as follows:

Efficacy for student engagement - "How much can you do to control disruptive behavior in the classroom?"

Efficacy for instructional strategies - "How much can you do to adjust your lessons to the proper level for individual students?"

Efficacy for classroom management - "How well can you establish routines to keep activities running smoothly?"

To facilitate the analysis, the author sorted item numbers on subscales efficacy for student engagement, efficacy for instructional strategies, and efficacy for classroom management. The order of TSES items on a subscale efficacy for student engagement is 1, 2, 4, 6, 9, 12, 14, and 22; in this research, it was changed into $1,2,3,4,5,6,7$, and 8 . The order of TSES items on a subscale efficacy for instructional strategy is $7,10,11,17,18,20,23$ and 24 ; in this research, it was changed into $13,15,14,9,16,10,11$, and 12. The order of TSES items on a subscale efficacy for classroom management is $3,5,8,13,15,16,19$ and 21; in this research, it was changed into $21,20,17,18,22,19,23$, and 24 . The order of numbering shows in Table 2.

Table 2. The Numbering used in Indonesia Version of Teachers' Sense of Efficacy Scale

\begin{tabular}{|l|l|l|} 
Efficacy for student & Efficacy for instructional & Efficacy for classroom
\end{tabular}




\begin{tabular}{|c|c|c|c|c|c|}
\hline \multicolumn{2}{|c|}{ engagement } & \multicolumn{2}{|c|}{ strategies } & \multicolumn{2}{|c|}{ management } \\
\hline $\begin{array}{l}\text { Original } \\
\text { number }\end{array}$ & $\begin{array}{c}\text { New number } \\
\text { (Code) }\end{array}$ & $\begin{array}{l}\text { Original } \\
\text { number }\end{array}$ & $\begin{array}{c}\text { New number } \\
\text { (Code) }\end{array}$ & $\begin{array}{l}\text { Original } \\
\text { number }\end{array}$ & $\begin{array}{c}\text { New number } \\
\text { (Code) }\end{array}$ \\
\hline 1 & 1 (SE1) & 7 & 13 (IS1) & 3 & 21 (CM1) \\
\hline 2 & 2 (SE2) & 10 & 15 (IS2) & 5 & 20 (CM2) \\
\hline 4 & 3 (SE3) & 11 & 14 (IS3) & 8 & 17 (CM3) \\
\hline 6 & 4 (SE4) & 17 & 9 (IS4) & 13 & 18 (CM4) \\
\hline 9 & 5 (SE5) & 18 & 16 (IS5) & 15 & 22 (CM5) \\
\hline 12 & 6 (SE6) & 20 & 10 (IS6) & 16 & 19 (CM6) \\
\hline 14 & 7 (SE7) & 23 & 11 (IS7) & 19 & 23 (CM7) \\
\hline 22 & 8 (SE8) & 24 & 12 (IS8) & 21 & 24 (CM8) \\
\hline
\end{tabular}

\section{Procedures}

To achieve the goal of producing a translated version of the TSES instrument and to preserve the meaning and purpose of the original instrument items, the researcher followed the process listed in Figure 1.

Stage 1. The first stage was the transfer of language (translation) from English to Indonesian by two linguists. One of these linguists is an expert in the field of self-efficacy as well. After the translation, the meaning of the sentence was checked so that the Indonesian sentences contain the same meaning as the original sentences in English. Due to cultural and linguistic differences, there were some minor differences between the words in TSES and the translated version to preserve the meaning of each item.

Stage 2. The second stage was interviews with five elementary school teachers in Indonesia to check the clarity of the statements. This interview was conducted to determine whether the meaning of the sentence in the translation matches the original meaning. Interviewed elementary school teachers were asked to read each instrument item. Then, they were asked about the meaning of each item that was read. When there was a teacher who did not understand the meaning correctly, the teacher was asked to provide a suggested sentence so that the items match the intended meaning.

Stage 3. The third stage was field-testing the translated and revised instruments. Field trials were conducted on 95 elementary school teachers in Purbalingga District. Then, a statistical test was performed to determine the validity and reliability of Indonesian translated TSES. Validity analysis of the Indonesian translated TSES was construct validity through Confirmatory Factor Analysis (CFA). The reliability was analyzed using Alpha-Cronbach Reliability. Data obtained from the study were analyzed using SPSS 23 and LISREL 8.80 programs. Henceforth, the translated and revised TSES instrument is called the Indonesian version of Teachers' Sense of Efficacy Scale (I-TSES).

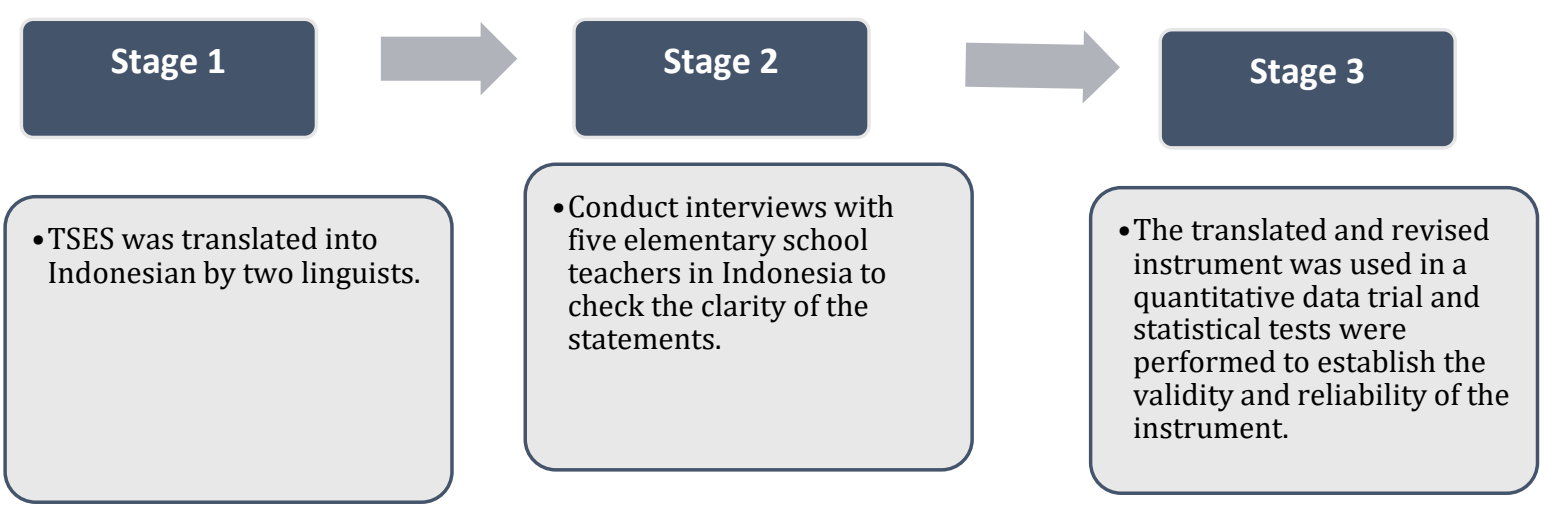

Figure 1. Research framework

\section{Data Analysis}

Respondents were asked to respond to 24 items of the I-TSES instrument. The efficacy subscale for student engagement consisted of 8 question items that were coded as SE1-SE8; the efficacy for instructional strategies subscale consisted of 8 question items that were coded as IS1-IS8; the efficacy for classroom management subscale consists of 8 question items that were coded as CM1-CM8. Lisrel version 8.80 was used to conduct Confirmatory Factor Analysis (CFA) to test the validity of the instrument constructs used by elementary school teachers in Indonesia. 
Confirmatory factor analysis was used to assess the TSES model consisting of 3 predefined subscales: efficacy for student engagement, efficacy for instructional strategies, and efficacy for classroom management. The analysis used maximum likelihood estimation and all analysis shown in the variancecovariance matrix.

The fit indices described in this study included the Root Mean Square Error of Approximation (RMSEA), Normed Fit Index (NFI), Non-Normed Fit Index (NNFI), Incremental Fit Index (IFI), and Comparative Fit Index (CFI) (Yadama \& Pandey, 1995). RMSEA value of .05 or lower is a value that is close to fit with the model in relation to the degree of freedom; RMSEA value of .08 or lower indicates a reasonable error estimation (Browne \& Cudeck, 1993; Marsh, Balla, \& Mcdonald, 1988). NFI value $\geq .90$ is accepted value (P. M. Bentler, 1990; Peter M. Bentler, 1992; Marsh et al., 1988; Yadama \& Pandey, 1995). NNFI value $\geq .90$ is accepted value (P. M. Bentler, 1990; P. M. Bentler \& Bonett, 1980; Yadama \& Pandey, 1995). IFI value $\geq .90$ is an accepted value (P. M. Bentler, 1990; Bollen, 1989; Yadama \& Pandey, 1995). CFI value close to 1 indicates a very fit value (Arbuckle, 2012) and a CFI value of .9 is an acceptable value (P. M. Bentler, 1990; Kline, 2011; Yadama \& Pandey, 1995).

\section{RESULTS}

\section{Normative Data}

\section{Modification of the Measurement Model}

Prior to conducting Confirmatory Factor Analysis procedures, data were subjected to test of multivariate normality (Jr., Black, Babin, \& Anderson, 2014). Both the skewness (skewness = -.732, SE = .247) and kurtosis (kurtosis $=-.007, \mathrm{SE}=.490$ ) of the distribution were within acceptable limits (Jr. et al., 2014), and the Kolmogorov Smirnov suggested that the data sample were drawn from a normally distributed population ( $\mathrm{sig}=.012$ ). The shape of normal probability plots also shown a normal distribution.

The result of Confirmatory Factor Analysis using Lisrel 8.80 that was conducted to 95 samples showed: $\chi^{2}=486.53(\mathrm{df}=249)$; RMSEA = .10; CFI = .98; IFI = .98; NNFI = .97; and NFI = .95. From this data, it is known that RMSEA could not be claimed as fit yet because they were more than the set standard. Data modification was required so that the model gets better, and RSMEA was reduced (Brown, 2015; Harrington, 2009; O’Rourke \& Hatcher, 2013). Modifications in this study were carried out by changing the path according to the modification indices provided by Lisrel (Brown, 2015; Harrington, 2009).

Table 3. Fit indices for the measurement of the original I-TSES and modification models

\begin{tabular}{|c|c|c|c|c|c|c|}
\hline $\begin{array}{c}\text { Goodness- } \\
\text { of-fit }\end{array}$ & Original & $\begin{array}{c}\mathbf{1}^{\text {st }} \\
\text { Modification }\end{array}$ & $\begin{array}{c}\mathbf{2}^{\text {nd }} \\
\text { Modification }\end{array}$ & $\begin{array}{c}\mathbf{3}^{\text {rd }} \\
\text { Modification }\end{array}$ & $\begin{array}{c}\mathbf{4}^{\text {th }} \\
\text { Modification }\end{array}$ & $\begin{array}{c}\mathbf{5}^{\text {th }} \\
\text { Modification }\end{array}$ \\
\hline RMSEA & .10 & .094 & .082 & .078 & .071 & .068 \\
\hline CFI & .98 & .98 & .98 & .98 & .98 & .98 \\
\hline IFI & .98 & .98 & .98 & .98 & .98 & .99 \\
\hline NNFI & .97 & .97 & .98 & .98 & .98 & .98 \\
\hline NFI & .96 & .95 & .95 & .96 & .96 & .96 \\
\hline
\end{tabular}

\section{Step-by-Step Analyses}

From the analysed results, the first modification was made by changing the paths in SE6 (item number 6), IS1 (item number 9), CM3 (item number 19), and CM5 (item number 21). Item SE6 that was previously included in subscale SE (efficacy for student engagement) had to be revised into two subscales at once; those are IS (efficacy for instructional strategies) and CM (efficacy for classroom management). Item IS1 that was previously included in subscale IS, had to be revised into subscale SE. Item CM3 that was previously included in subscale $\mathrm{CM}$ had to be revised into two subscales at once; SE and IS. Item CM5 that was previously included in subscale CM had to be revised into two subscales at once; SE and IS. Step-bystep modification showed in Table 3.

After the modification, the obtained result are: $\chi^{2}=451.69(\mathrm{df}=246)$; RMSEA $=.094 ; \mathrm{CFI}=.98$; IFI $=.98$; NFI = .97; and NFI = .95. This model still showed poor fit or a weak compatibility level. From the results of this modification, Lisrel 8.80 suggested to change the original IS6 pathway from IS to CM, and then add a path from CM5 to CM so that these CM5 items fit into three subscales at once.

Modifications were conducted again using the advice given by Lisrel 8.80. From the results of this second modification, the obtained results are: $\chi^{2}=398.77(\mathrm{df}=245)$; $\mathrm{RMSEA}=.082 ; \mathrm{CFI}=.98 ; \mathrm{IFI}=.98$; 
NNFI = .98; and NFI $=.96$. This model still showed poor fit or a weak compatibility level because RMSEA greater than .80 .

Table 4. Fit indices for the measurement of the I-TSES revised models 5

\begin{tabular}{|c|c|c|c|}
\hline Goodness-of-fit & Value & Criteria & Meaning \\
\hline RMSEA & .068 & $<.08$ & Fit \\
\hline CFI & .98 & $\geq .90$ & Fit \\
\hline IFI & .99 & $\geq .90$ & Fit \\
\hline NNFI & .98 & $\geq .90$ & Fit \\
\hline NFI & .96 & $\geq .90$ & Fit \\
\hline
\end{tabular}

Modifications continues until fifth modification. The results on Table 4 showed: $\chi^{2}=348.35 \mathrm{ddf}=$ 242); $\mathrm{RMSEA}=.068$; CFI $=.98$; $\mathrm{IFI}=.99 ; \mathrm{NNFI}=.98$; and NFI $=.96$. This modification showed an acceptable RMSEA value of less than .08. CFI, IFI, NNFI, and NFI values showed to be a good fit because they were greater than .90 . The new structure of I-TSES test results after the modification can be seen in table 5 and figure 2.

Table 5. The new structure of I-TSES after revised

\begin{tabular}{|c|c|c|c|c|}
\hline \multirow{2}{*}{ Code } & \multirow{2}{*}{ Item } & \multicolumn{3}{|c|}{ Subscale } \\
\hline & Number & SE & IS & CM \\
\hline SE1 & 1 & $\checkmark$ & & \\
\hline SE2 & 2 & $\checkmark$ & & \\
\hline SE3 & 3 & $\checkmark$ & & \\
\hline SE4 & 4 & $\checkmark$ & & \\
\hline SE5 & 5 & $\checkmark$ & & \\
\hline SE6 & 6 & & $\checkmark$ & $\checkmark$ \\
\hline SE7 & 7 & $\checkmark$ & & \\
\hline SE8 & 8 & & $\checkmark$ & \\
\hline IS1 & 13 & $\checkmark$ & & \\
\hline IS2 & 15 & & $\checkmark$ & \\
\hline IS3 & 14 & & $\checkmark$ & \\
\hline IS4 & 9 & & $\checkmark$ & \\
\hline IS5 & 16 & & $\checkmark$ & \\
\hline IS6 & 10 & & & $\checkmark$ \\
\hline IS7 & 11 & & $\checkmark$ & \\
\hline IS8 & 12 & & $\checkmark$ & \\
\hline CM1 & 21 & & $\checkmark$ & $\checkmark$ \\
\hline CM2 & 20 & & & $\checkmark$ \\
\hline CM3 & 17 & $\checkmark$ & $\checkmark$ & \\
\hline CM4 & 18 & & & $\checkmark$ \\
\hline CM5 & 22 & $\checkmark$ & $\checkmark$ & $\checkmark$ \\
\hline CM6 & 19 & & $\checkmark$ & $\checkmark$ \\
\hline CM7 & 23 & & $\checkmark$ & $\checkmark$ \\
\hline CM8 & 24 & & & $\checkmark$ \\
\hline
\end{tabular}

Note. SE = efficacy for student engagement; IS = efficacy for instructional strategy; $\mathrm{CM}=$ efficacy for classroom management.

\section{Internal Consistency Reliabilities}

The measure of reliability verification for personality variables usually only has medium reliability, which is between .60 to .70 (Ary, Jacobs, \& Sorensen, 2010). In this study, the I-TSES instrument as a whole and each subscale have high reliability because the results of the proof showed a score of more than .90 . Table 6 shows a recapitulation of the results on the verification of reliability for the entire instrument, subscales efficacy for student engagement, efficacy for instructional strategies, and efficacy for classroom management. 
Table 6. Alpha-Cronbach reliability

\begin{tabular}{|l|c|}
\hline \multicolumn{1}{|c|}{ Instrument } & Alpha-Cronbach \\
\hline I-TSES & .977 \\
\hline Efficacy for student engagement & .941 \\
\hline Efficacy for instructional strategies & .962 \\
\hline Efficacy for classroom management & .961 \\
\hline
\end{tabular}

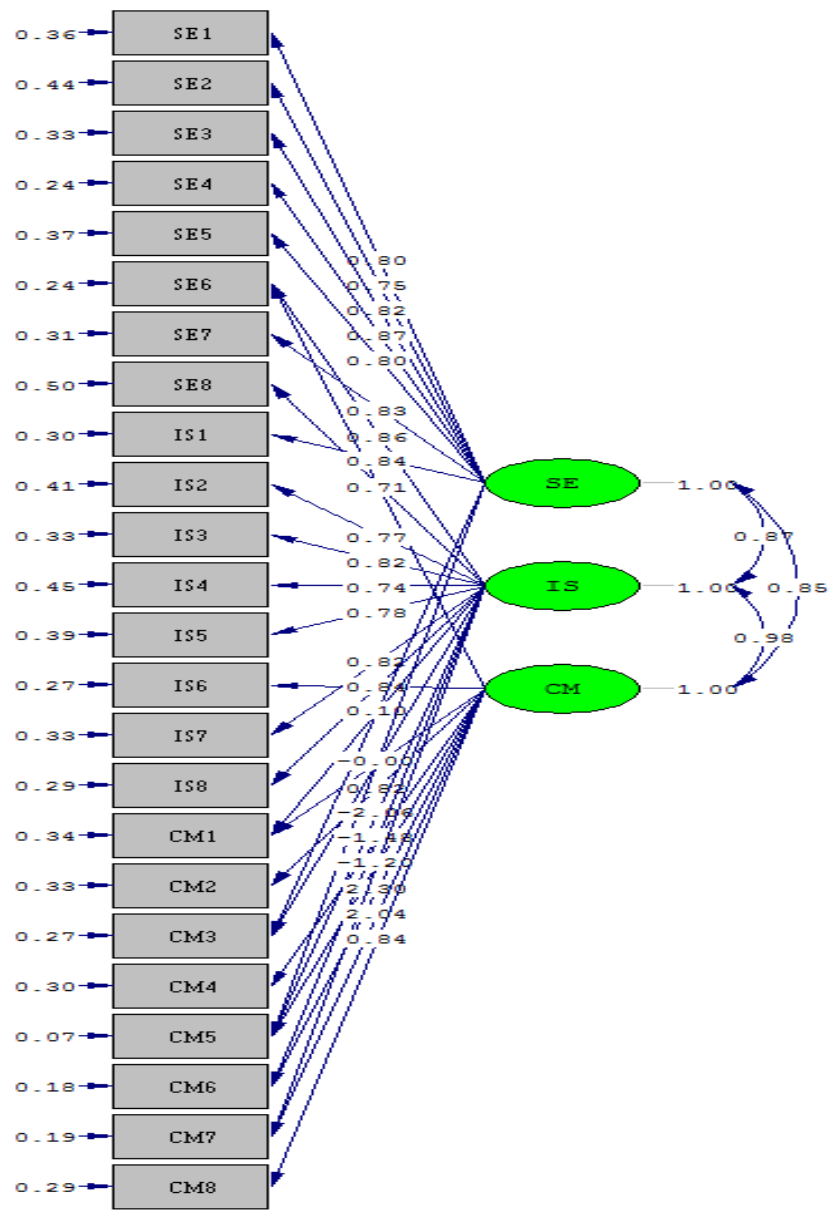

Figure 2. Three factor CFA model of I-TSES

\section{DISCUSSION and CONCLUSIONS}

TSES is one of the most widely used measurement instruments for teacher self-efficacy (Kleinsasser, 2014). TSES has been adapted to many languages, but there has been no adaptation into Indonesian yet. This study seeks to adapt TSES into Indonesian (I-TSES) and test the construct using CFA. The results of the study showed a difference with the results obtained by Tschannen-moran \& Hoy (2001).

From the test results, it was known that I-TSES was classified as a fit instrument. However, RMSEA values were slightly higher than the acceptable limit. It could be caused by various things, including factors that were too little or too much, choosing the wrong indicators, or the loading pattern of the factors that were not right (Harrington, 2009). In this case, there was caused by a mismatch in the path between indicators and factors (Brown, 2015) that it needed modification. From the results of modification, it was known that there were indicators that, in fact, not only prominent in one factor, but in two or more factors (Brown, 2015). For instance, the SE6 indicator was prominent on two factors (efficacy for instructional strategies and efficacy for classroom management), and the CM5 were prominent in all factors (efficacy for student engagement, efficacy for instructional strategies and efficacy for classroom management). 
CFA relies heavily on strong conceptual / constructs (Brown, 2015). Thus, the mismatch of these indicators might also be caused by the lack of maturity of the construct made by Tschannen-moran \& Hoy (2001). As a result of the search, the researchers did not find any literature that shows the relationship between the factors in Tschannen-moran \& Hoy's previous publications. Thus, the literature used by Tschannen-Moran \& Hoy to classify TSES indicators into three factors (efficacy for student engagement, efficacy for instructional strategies and efficacy for classroom management) is unknown.

The test results prove that the I-TSES is different from the TTSES (Turkish version of the Teacher' Sense of Efficacy Scale), which was not modified (Çapa et al., 2005). At the time of testing, TTSES was declared fit with RMSEA .065 and CFI .99 (Çapa et al., 2005). This difference might be due to different samples, TSES and TTSES samples were pre-service teachers from various fields (Çapa et al., 2005; Duffin et al., 2012) while the I-TSES samples were in-service elementary school teachers. The research shows that in-service teachers have higher levels of self-efficacy than pre-service teachers (Putman, 2012). But it is also quite common that some researches show no difference of level of self-efficacy between in-service and pre-service teachers (Bedİr, 2015; Chan, 2008).

The cultural difference was also one of the considerations that determine the differences in the results of this test. Although this self-efficacy has been researched for many years to date, it has not been explored thoroughly in most countries outside the United States/US (Duffin et al., 2012). Some literature states that cross-culture becomes one of the contributing factors of teacher self-efficacy (Duffin et al., 2012; Manzar-abbas \& Lu, 2015; Murshidi et al., 2006; Tschannen-moran \& Woolfolk, 2007). Cultural differences in the US, Turkey, and Indonesia may be one of the factors causing differences in testing results.

Based on the test results, I-TSES can be used to assess teacher self-efficacy in the Indonesian region. The results of the I-TSES assessment can be used to determine the right training program to improve teacher professionalism in teaching (Rahayu, Sartono, \& Miftakhuddin, 2019). Teachers can also use I-TSES to assess the extent of their performance in teaching (Çapa et al., 2005). I-TSES is expected to be a teacher's self-assessment instrument to see the extent of the teacher's capability to teach.

This research inseparable from the limitations of the study. Some limitations of this study include using a small number of samples. Therefore, future research should be conducted with a larger samples to see whether the construct specified in this study is suitable for large samples. Future studies should involve pre-service teachers as samples, to prove whether the constructs in this study are appropriate for pre-service teachers. Future research also needs to be extended to other countries outside the US so that it can expand generalizations by looking at the cultural suitability of the TSES construct. By doing research in various countries, it can be analyzed whether the TSES construct can be used in other countries with different cultures (cross-cultural).

\section{ACKNOWLEDGEMENTS}

The author would like to thank profusely to the Lembaga Pengelola Dana Pendidikan (LPDP) as the funder of the author.

\section{REFERENCES}

Abu-tineh, A. M., Khasawneh, S. A., \& Khalaileh, H. A. (2011). Teacher self-efficacy and classroom management styles in Jordanian schools. Management in Education, 25(4), 175-181. https://doi.org/10.1177/0892020611420597

Arbuckle, J. L. (2012). IBM SPSS Amos 21 User's Guide. New York: Amos Development Corporation. https://doi.org/10.1111/j.1600-0447.2011.01711.x

Arsal, Z. (2014). Microteaching and pre-service teachers' sense of self-efficacy in teaching. European Journal of Teacher Education, 37(4), 453-464. https://doi.org/10.1080/02619768.2014.912627

Ary, D., Jacobs, L. C., \& Sorensen, C. (2010). Introduction to Research in Education. Belmont, CA: Wadsworth.

Bandura, A. (1977). Self-efficacy: Toward a unifying theory of behavioral change. Psychological Review, $84(2), 191-215$.

Bandura, A. (1988). Self-efficacy conception of anxiety. Anxiety Research: An International Journal, 1(2), 77-98. https://doi.org/http://dx.doi.org/10.1080/10615808808248222

Bandura, A. (1993). Perceived self-efficacy in cognitive development and functioning. Educational Psychologist, 28(2), 117-148. https://doi.org/10.1207/s15326985ep2802

Bandura, A. (1997). Self-efficacy: The exercise of control. New York: W. H. Freeman. https://doi.org/10.1007 
Bandura, A. (2005). Guide for Constructing Self-Efficacy Scales. In F. Pajares \& T. Urdan (Eds.), SelfEfficacy Beliefs of Adolescents (pp. 307-337). United States of America: Information Age Publishing.

Bedİr, G. (2015). Perception of teaching efficacy by primary and secondary school teachers. International Electronic Journal of Elementary Education, 8(1), 41-54.

Bekdemir, M. (2010). The pre-service teachers' mathematics anxiety related to depth of negative experiences in mathematics classroom while they were students. Educational Studies in Mathematics, 75, 311-328. https://doi.org/10.1007/s10649-010-9260-7

Bentler, P. M. (1990). Comparative fit indexes in structural models. Psychological Bulletin, 107(2), 238246.

Bentler, P. M., \& Bonett, D. G. (1980). Significance tests and goodness of fit in the analysis of covariance structures. Psychological Bulletin, 88(3), 588-606. https://doi.org/10.1037/0033-2909.88.3.588

Bentler, Peter M. (1992). On the fit of models to covariances and methodology to the Bulletin. Psychological Bulletin, 112(3), 400-404. https://doi.org/10.1037/0033-2909.112.3.400

Bergman, D. J., \& Morphew, J. (2015). Effects of a science content course on elementary preservice teachers' self-efficacy of teaching science. Research and Teaching, 44(3), 73-81.

Biasutti, M., \& Concina, E. (2018). The effective music teacher: The influence of personal, social, and cognitive dimensions on music teacher self-efficacy. Musicae Scientiae, 22(2), 1-16. https://doi.org/10.1177/1029864916685929

Bollen, K. A. (1989). Structural Equations with Latent Variable. Canada: John Wiley \& Sons, Inc.

Brown, T. A. (2015). Confirmatory Factor Analysis for Applied Research (Second Edi). New York: The Guilford Press.

Browne, M. W., \& Cudeck, R. (1993). Alternative Ways of Assessing Model Fit. In K. A. Bollen \& J. S. Long (Eds.), Testing Structural Equation Models. Newbury Park, California: Sage Publication, Inc.

Buss, R. R. (2010). Efficacy for teaching elementary science and mathematics compared to other content. School Science and Mathematics, 110(6), 290-297. https://doi.org/10.1111/j.19498594.2010.00037.x

Cansoy, R., \& Parlar, H. (2018). Examining the relationship between school principals' instructional leadership behaviors, teacher self-efficacy, and collective teacher efficacy. International Journal of Educational Management, 32(4), 550-567. https://doi.org/https://doi.org/10.1108/IJEM-04-20170089

Çapa, Y., Çakıroğlu, J., \& Sarıkaya, H. (2005). The Development and Validation of a Turkish Version of the Teacheis' Sense of Efficacy Scale. Education and Science, 30(137), 74-81.

Chan, D. W. (2008). Dimensions of teacher self-efficacy among Chinese secondary school teachers in Hong Kong. Educational Psychology, 28(2), 181-194. https://doi.org/10.1080/01443410701491833

Chang, Y. L. (2015). Examining relationships among elementary mathematics teachers' efficacy and their students' mathematics self-efficacy and achievement. Eurasia Journal of Mathematics, Science and Technology Education, 11(6), 1307-1320. https://doi.org/10.12973/eurasia.2015.1387a

Chao, C. N. G., Forlin, C., \& Ho, F. C. (2016). Improving teaching self-efficacy for teachers in inclusive classrooms in Hong Kong. International Journal of Inclusive Education, 20(11), 1142-1154. https://doi.org/10.1080/13603116.2016.1155663

Cheung, H. Y. (2008). Teacher efficacy: A comparative study of Hong Kong and Shanghai primary inservice teachers. Australian Educational Researcher, 35(1), 103-123. https://doi.org/10.1007/BF03216877

Clark, S., \& Newberry, M. (2018). Are we building preservice Teacher self-efficacy? A large-scale study examining Teacher education experiences. Asia-Pacific Journal of Teacher Education, 47(1), 32-47. https://doi.org/10.1080/1359866X.2018.1497772

Coates, T. J., \& Thoresen, C. E. (1976). Teacher anxiety: A review with recommendations. Review of Educational Research, 46(2), 159-184. https://doi.org/10.3102/00346543046002159

Dembo, M. H., \& Gibson, S. (1985). Teachers' sense of efficacy: An important factor in school improvement. The Elementary School Journal, 86(2), 173-184. https://doi.org/10.1086/461441

Duffin, L. C., French, B. F., \& Patrick, H. (2012). The Teachers' Sense of Efficacy Scale: Confirming the factor structure with beginning pre-service teachers. Teaching and Teacher Education, 28(6), 827-834. https://doi.org/10.1016/j.tate.2012.03.004

Evans, N. S., Tomas, L., \& Woods, C. (2016). Impact of sustainability pedagogies on pre-service teachers' self-efficacy. Journal of Education for Sustainable Development, 10(2), 1-19.

Forlin, C., Sharma, U., \& Loreman, T. (2014). Predictors of improved teaching efficacy following basic training for inclusion in Hong Kong. International Journal of Inclusive Education, 18(7), 718-730. https://doi.org/10.1080/13603116.2013.819941

Gibson, S., \& Dembo, M. H. (1984). Teacher efficacy: A construct validation. Journal of Educational 
Psychology, 76(4), 569-582.

Giles, R. M. M., Byrd, K. O., \& Bendolph, A. (2016). An investigation of elementary preservice teachers' selfefficacy for teaching mathematics. Cogent Education, 3(1), 1-11. https://doi.org/10.1080/2331186X.2016.1160523

Guo, Y., Connor, C. M., Yang, Y., Roehrig, A. D., \& Morrison, F. J. (2012). The effects of teacher qualification, teacher self-efficacy, and classroom practices on fifth graders' literacy outcomes. The Elementary School Journal, 113(1), 3-24. https://doi.org/10.1086/665816

Gür, G., Çakiroğlu, J., \& Çapa, Y. (2012). Investigating predictors of sense of efficacy beliefs of classroom, science, and mathematics teachers. Education and Science, 37(166), 68-76.

Harrington, D. (2009). Confirmatory Factor Analysis: Pocket Guides to Social Work Research Methods. New York: Oxford University Press, Inc.

Jr., J. F. H., Black, W. C., Babin, B. J., \& Anderson, R. E. (2014). Multivariate Data Analysis (Seventh Ed). Harlow: Pearson Education Limited. https://doi.org/10.1002/9781118895238.ch8

Kim, K. R., \& Seo, E. H. (2018). The relationship between teacher efficacy and students' academic achievement: A meta-analysis. Social, 46(4), 529-540.

Kleinsasser, R. C. (2014). Teacher efficacy in Teaching and Teacher Education. Teaching and Teacher Education, 44, 168-179. https://doi.org/10.1016/j.tate.2014.07.007

Kline, R. B. (2011). Principles and Practice of Structural Equation Modeling (Third Edit). New York: The Guilford Press.

Krejcie, R. V., \& Morgan, D. W. (1970). Determining sample size for research activities. Educational and Psychological Measurement, 30, 607-610.

Liu, S., \& Hallinger, P. (2018). Principal instructional leadership, teacher self-efficacy, and teacher professional learning in China: Testing a mediated-effects model. Educational Administration Quarterly, 54(4), 501-528. https://doi.org/10.1177/0013161X18769048

Manzar-abbas, S. S., \& Lu, L. (2015). Self-efficacy beliefs of chinese primary school teachers. Pakistan Journal of Psychological Research, 30(2), 289-303.

Marsh, H. W., Balla, J. R., \& Mcdonald, R. P. (1988). Goodness-of-Fit Indexes in confirmatory factor analysis : The effect of sample size. Psychological Bulletin, 103(3), 391-410.

Menon, D., \& Sadler, T. D. (2016). Preservice elementary teachers' science self-efficacy beliefs and science content knowledge. Journal of Science Teacher Education, 27(6), 649-673. https://doi.org/10.1007/s10972-016-9479-y

Murshidi, R., Konting, M. M., Elias, H., \& Fooi, F. S. (2006). Sense of efficacy among beginning teachers in Sarawak. Teaching Education, 17(3), 265-275. https://doi.org/10.1080/10476210600849730

Nurlu, Ö. (2015). Investigation of teachers' mathematics teaching self-efficacy. International Electronic Journal of Elementary Education, 8(1), 21-40.

O'Rourke, N., \& Hatcher, L. (2013). Step-by-Step Approach to Using SAS ${ }^{\circledR}$ for Factor Analysis and Structural Equation Modeling (Second Edi). Cary, NC: SAS Institute Inc.

Putman, S. M. (2012). Investigating teacher efficacy: Comparing preservice and inservice teachers with different levels of experience. Action in Teacher Education, 34(1), 26-40. https://doi.org/10.1080/01626620.2012.642285

Rahayu, L. P., Sartono, E. K. E., \& Miftakhuddin. (2019). Self-efficacy of primary school teachers in mathematics teaching: A comparative research on teacher training program products. Mimbar Sekolah Dasar, 6(1), 68-78. https://doi.org/10.17509/mimbar-sd.v6i1.15122

Ramirez, G., Hooper, S. Y., Kersting, N. B., Ferguson, R., \& Yeager, D. (2018). Teacher math anxiety relates to adolescent students' math achievement. AERA Open, 4(1), 1-13. https://doi.org/10.1177/2332858418756052

Saklofske, D. H., Michayluk, J. O., \& Randhawa, B. S. (1988). Teachers' efficacy and teaching behaviors. Psychological Reports, 63(2), 407-414. https://doi.org/10.2466/pr0.1988.63.2.407

Santrock, J. W. (2011). Educational Psychology (Fifth Edit). New York: McGraw-Hill.

Senler, B. (2016). Pre-service science teachers' self-efficacy: The role of attitude, anxiety and locus of control. Australian Journal of Education, 60(1), 1-16. https://doi.org/10.1177/0004944116629807

Septiana, D. (2018). The influence of emotional intelegence, self-efficacy, and altruism on teacher's competence in inclusion elementary school. Jurnal Prima Edukasia, 6(2), 147-156. https://doi.org/10.21831/jpe.v6i2.14413

Swanson, P. (2014). The power of belief: Spanish teachers ' sense of efficacy and student performance on the National Spanish Examinations. American Association of Teachers of Spanish and Portuguese, 97(1), 5-20.

Tschannen-moran, M., \& Hoy, A. W. (2001). Teacher efficacy: Capturing an elusive construct. Teaching and Teacher Education, 17, 783-805. https://doi.org/10.1016/S0742-051X(01)00036-1 
Tschannen-Moran, M., Hoy, A. W., \& Hoy, W. K. (1998). Teacher efficacy : Its meaning and measure. Review of Educational Research, 68(2), 202-248.

Tschannen-moran, M., \& Woolfolk, A. (2007). The differential antecedents of self-efficacy beliefs of novice and experienced teachers. Teaching and Teacher Education, 23, 944-956. https://doi.org/10.1016/j.tate.2006.05.003

Wahyuni, N. D., \& Jailani, J. (2017). Pengaruh pendekatan matematika realistik terhadap motivasi dan prestasi belajar siswa SD. Jurnal Prima Edukasia, 5(2), 151-159. https://doi.org/10.21831/jpe.v5i2.7785

Woolfolk, A. E., \& Hoy, W. K. (1990). Prospective teachers' sense of efficacy and beliefs about control. Journal of Educational Psychology, 82(1), 81-91.

Yada, A., Tolvanen, A., Malinen, O. P., Imai-Matsumura, K., Shimada, H., Koike, R., \& Savolainen, H. (2019). Teachers' self-efficacy and the sources of efficacy: A cross-cultural investigation in Japan and Finland. Teaching and Teacher Education, 81, 13-24. https://doi.org/10.1016/j.tate.2019.01.014

Yadama, G. N., \& Pandey, S. (1995). Effect of sample size on goodness-fit of-fit indices in structural equation models. Journal of Social Service Research, 20(3-4), 49-70. https://doi.org/10.1300/J079v20n03_03

Zee, M., \& Koomen, H. M. Y. (2016). Teacher self-efficacy and its effects on classroom processes, student academic adjustment, and teacher well-being: A synthesis of 40 years of research. Review of Educational Research, $X X(X), 1-35$. https://doi.org/10.3102/0034654315626801

APPENDIX

\begin{tabular}{|c|c|c|}
\hline Code & $\begin{array}{l}\text { Item } \\
\text { Number }\end{array}$ & Item \\
\hline SE1 & 1 & $\begin{array}{l}\text { Seberapa mampu Bapak/Ibu mengatasi siswa yang paling sulit/menyulitkan ketika } \\
\text { pembelajaran? }\end{array}$ \\
\hline SE2 & 2 & Seberapa mampu Bapak/Ibu membantu siswa untuk berpikir kritis? \\
\hline SE3 & 3 & $\begin{array}{l}\text { Seberapa mampu Bapak/Ibu memotivasi siswa yang memiliki minat rendah pada } \\
\text { pembelajaran? }\end{array}$ \\
\hline SE4 & 4 & $\begin{array}{l}\text { Seberapa mampu Bapak/Ibu membuat siswa percaya bahwa mereka dapat } \\
\text { mengerjakan tugas dengan baik? }\end{array}$ \\
\hline SE5 & 5 & Seberapa mampu Bapak/Ibu membantu siswa menghargai pembelajaran? \\
\hline SE6 & 6 & Seberapa mampu Bapak/Ibu meningkatkan kreativitas siswa? \\
\hline SE7 & 7 & $\begin{array}{l}\text { Seberapa mampu Bapak/Ibu meningkatkan pemahaman siswa yang kurang } \\
\text { berprestasi dalam pelajaran? }\end{array}$ \\
\hline SE8 & 8 & $\begin{array}{l}\text { Seberapa mampu Bapak/Ibu bekerjasama dengan orangtua dalam membantu anak- } \\
\text { anak untuk berprestasi dalam pembelajaran? }\end{array}$ \\
\hline IS1 & 13 & $\begin{array}{l}\text { Seberapa mampu Bapak/Ibu menyesuaikan pembelajaran berdasarkan tingkat } \\
\text { kemampuan masing-masing siswa? }\end{array}$ \\
\hline IS2 & 15 & $\begin{array}{l}\text { Seberapa mampu Bapak/Ibu memberikan penjelasan atau contoh alternatif ketika } \\
\text { siswa bingung mengikuti pembelajaran? }\end{array}$ \\
\hline IS3 & 14 & $\begin{array}{l}\text { Seberapa mampu Bapak/Ibu menggunakan strategi pembelajaran alternatif ketika } \\
\text { strategi pembelajaran yang biasa Bapak/Ibu lakukan tidak berhasil? }\end{array}$ \\
\hline IS4 & 9 & $\begin{array}{l}\text { Seberapa mampu Bapak/Ibu memberikan tantangan yang tepat kepada siswa yang } \\
\text { sangat pandai? }\end{array}$ \\
\hline IS5 & 16 & Seberapa mampu Bapak/Ibu menjawab pertanyaan sulit dari siswa? \\
\hline IS6 & 10 & Seberapa mampu Bapak/Ibu membuat pertanyaan yang bagus untuk siswa? \\
\hline IS7 & 11 & $\begin{array}{l}\text { Seberapa mampu Bapak/Ibu mengukur pemahaman siswa tentang pembelajaran } \\
\text { yang telah diajarkan? }\end{array}$ \\
\hline IS8 & 12 & Seberapa mampu Bapak/Ibu menggunakan berbagai teknik penilaian? \\
\hline CM1 & 21 & $\begin{array}{l}\text { Seberapa mampu Bapak/Ibu membuat pembiasaan di kelas agar kegiatan } \\
\text { pembelajaran berjalan dengan lancar? }\end{array}$ \\
\hline CM2 & 20 & Seberapa mampu Bapak/Ibu membuat siswa mengikuti aturan kelas? \\
\hline CM3 & 17 & $\begin{array}{l}\text { Seberapa mampu Bapak/Ibu mengorganisasikan kelas yang berbeda kemampuan } \\
\text { siswanya sehingga hasil pembelajaran dapat optimal? }\end{array}$ \\
\hline CM4 & 18 & Seberapa mampu Bapak/Ibu menjelaskan harapan/aturan terkait perilaku siswa di \\
\hline
\end{tabular}




\begin{tabular}{|c|c|l|l|}
\hline CM5 & 22 & $\begin{array}{l}\text { kelas? } \\
\text { keberapa mampu Bapak/Ibu mengendalikan perilaku siswa yang mengganggu } \\
\text { ketika pembelajaran? }\end{array}$ \\
\hline CM6 & 19 & $\begin{array}{l}\text { Seberapa mampu Bapak/Ibu mengondisikan siswa yang ramai ketika } \\
\text { pembelajaran? }\end{array}$ \\
\hline CM7 & 23 & $\begin{array}{l}\text { Seberapa mampu Bapak/Ibu mencegah sebagian kecil siswa yang bermasalah agar } \\
\text { tidak mengganggu (merusak) pembelajaran? }\end{array}$ \\
\hline CM8 & 24 & $\begin{array}{l}\text { Seberapa mampu Bapak/Ibu merespon siswa yang selalu berperilaku menyimpang } \\
\text { di kelas? }\end{array}$ \\
\hline
\end{tabular}

